\title{
Diurnal Migration of Zooplankton in Inner Ambon Bay, Indonesia
}

\author{
Domey Moniharapon \\ Departemen Marine Science and Technology, Faculty of Fisheries and Marine Science \\ Bogor Agricultural University. Jln Raya Dramaga. IPB. Bogor
}

\author{
Indra Jaya
}

Departemen Marine Science and Technology, Faculty of Fisheries and Marine Science Bogor Agricultural University. Jln Raya Dramaga. IPB. Bogor

Hendrik Manik

Departemen Marine Science and Technology, Faculty of Fisheries and Marine Science Bogor Agricultural University. Jln Raya Dramaga. IPB. Bogor

\section{Sri Pujiyati}

Departemen Marine Science and Technology, Faculty of Fisheries and Marine Science Bogor Agricultural University. Jln Raya Dramaga. IPB. Bogor

\section{Totok Hestirianoto}

Departemen Marine Science and Technology, Faculty of Fisheries and Marine Science Bogor Agricultural University. Jln Raya Dramaga. IPB. Bogor

\section{Augy Syaihailatua}

Marine Life Conservation 3.Balai Ambon. Indonesian Institute of Sciences, Ambon

Received: July 27, 2014 Accepted: August 9, 2014

doi:10.5296/jas.v3i1.6603 URL: http://dx.doi.org/10.5296/jas.v3i1.6603 


\section{Abstract}

The study aims to analyze diurnal migration of zooplankton in Ambon Bay. Data sampling method which is conducted stationary utilizes pontoon mooring as floating platform for acoustic data sampling. Based on the analysis, diurnal migration of zooplankton occurs at noon, zooplankton swims in water surface to epipelagic zone $(0-20 \mathrm{~m})$ with value of scattering volume value $-90.13 \mathrm{~dB}$ to $-100.30 \mathrm{~dB}$; it indicates sparse and scattered aggregation $(\mathrm{N}=128)$. At night, scattering volume of $-90.01 \mathrm{~dB}$ to $-100.30 \mathrm{~dB}$ indicates dense and concentrated aggregation $(\mathrm{N}=75)$. Scattering volume is numerical expression of zooplankton density. Chlorophyll a concentration in depth of 0-10 meter having the highest value of $5.16 \mathrm{ppb}$ highly affects the existence of zooplankton. It functions for food availability of pelagic fish as its carnivore.

Keywords: Diurnal migration, Acoustic, Zooplankton, Scattering volume

\section{Introduction}

Role of zooplankton in waters is crucial since it is one of elements in oceanic food chain. For almost four decades, scientists have discussed about challenge to utilize underwater noise measurement for marine organism research, specifically for fishes and zooplankton (Beamish, 1971; Holiday and Pieper, 1980; Stanton et al., 1998).

Diel vertical migration, also known as diurnal vertical migration, of marine organisms is familiar phenomenon which is widely documented in literature (Everson, 1982). Hydroacoustics method is so effective and fast, and it is able to detect object in high resolution. Swiftness in interpreting data becomes prominent choice in research on fish resources potential.

Inner Ambon Bay is dynamic area connected to Banda Sea where the water exchange goes across Outer Ambon Bay. During upwelling in Banda Sea, thermocline is lower than the period when the upwelling does not occur; the phenomenon streams cold current from outer bay to inner bay. Factors like tidal currents and seasonal upwelling in Ambon Bay affect nutrient concentration, temperature, salinity, and zooplankton community structure (Wagey, 2002).

Inner Ambon Bay waters is semi-closed bay when every season period, in general, does not have waves, while the current is not great. Distance of both inter-thresholds in this bay is around $74 \mathrm{~m}$ and current speed is $<0.5 \mathrm{~m} / \mathrm{sec}$. While, the current speed of outer Ambon Bay reaches $>0.5 \mathrm{~m} / \mathrm{sec}$ and wind speed reaches $>18$ knot (Selanno, 2011).

Zooplankton functions a crucial role in pelagic system since it will determine organism life cycle above it, i.e. fish. Study on this community is crucial to be done since pelagic succession is highly affected by zooplankton. Researches on zooplankton have been conducted, one of them is Hays et al. (2005); these researchers assume that zooplankton belongs to key components of pelagic ecosystem and zooplankton is primary producer for higher trophic level.

As explained above, study on daily migration of zooplankton in Inner Ambon Bay has been undertaken. Concerning to the aim of study, it aims to analyze zooplankton daily migration in 


\section{Macrothink}

Inner Ambon Bay. It relates firmly to zooplankton distribution pattern as one of biological indicators in determining waters condition changes. Any findings would become contribution for Ambon Bay as fishing ground of baitfish.

\section{Methodology}

The study is conducted in Inner Ambon Bay having south latitude of $3^{0} 38^{\prime \prime} 46^{\prime}$ and east longitude of $128^{0} 12^{\prime} 24^{\prime}$, on September 14th, 2013. The study applies direct acoustic survey method on the object to be observed, in this concern is zooplankton in Ambon Bay. Study is conducted for 24 hours at the observed zone.
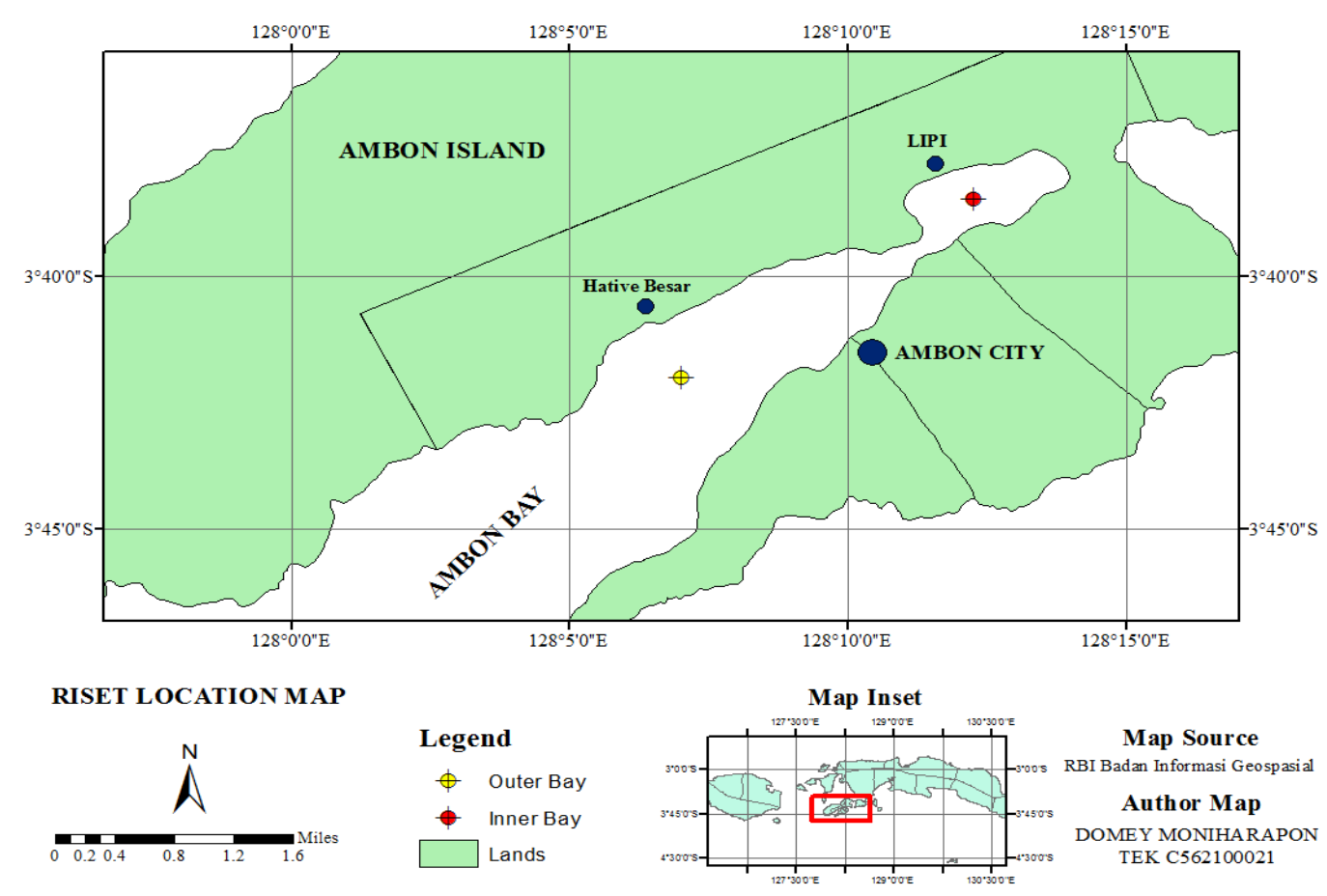

Figure 1. Map of Research Site

Cruz Pro transducer is placed next to mooring pontoon, this transducer placement in frequency of $200 \mathrm{kHz}$ is by side mounted system manner. Recording is continually undertaken for 24 hours. Recording product produces ASCII file which later on will be proceed by Matlab program version R2010a. Oceanography parameter measurement is proceeded by CTD-ALEC, model ASTD-687 where the measurement is taken by down time observation of every 2 hours. Data sampling of zooplankton is taken in a range of 5 meters to the bottom of the sea with time interval for data sampling of 3 hours by utilizing Van Dorn water sampler.

Volume of back-scattering is calculated in $\mathrm{dB}, \mathrm{SV}$ (Scattering Volume) depends on numerical types and abundance from scatters in volume unit which responds in form of reverse echo. Resulting scattering volume is summation of every zooplankton organism as formulated below (Stanton et al., 1994):

$$
S V=N_{a} \sigma_{a}+N_{b} \sigma_{b}=\sum_{i=1}^{m} N_{i} \sigma_{i}
$$




\section{Macrothink}

Description: $\sigma_{\mathrm{a}, \mathrm{b}}=$ Back Scattering Strength $(\mathrm{dB})$

$\mathrm{N}_{\mathrm{a}, \mathrm{b}}=$ Amount of species-based zooplankton

Sample of zooplankton is collected by utilizing Van Dorn water sampler, while species identification applies standard system for zooplankton identification. Abundance of zooplankton is calculated by the following formulation (Wickstead, 1965):

$$
\mathrm{D}=\mathrm{n} \times 1 / \mathrm{f} \times 1 / \mathrm{v} \quad\left(\mathrm{Ind} / \mathrm{m}^{3}\right)
$$

Description: $\mathrm{n}=$ Amount of individual zooplankton (tail)

$$
\begin{aligned}
& \mathrm{f}=\text { Utilized fraction }(\mathrm{ml}) \\
& \mathrm{v}=\text { Filtered water volume }(\mathrm{l})
\end{aligned}
$$

\section{Findings and Discussion}

\subsection{Aggregation Distribution of Zooplankton}

Acoustic data calculation makes average Scattering Volume $\left(\mathrm{SV}_{\text {average }}\right)$ based on time and depth as listed in Table 1.

Table 1. Value of Time- and Depth-based Scattering Volume

\begin{tabular}{|c|c|c|c|c|c|}
\hline \multirow{2}{*}{ Time } & \multicolumn{5}{|c|}{ Scattering Volume $(\mathrm{dB})$} \\
\cline { 2 - 6 } & $0-5$ & $5-10$ & $10-15$ & $15-20$ & $20-25$ \\
\hline 09:00-12:00 & -96.70 & -96.65 & -97.10 & - & - \\
12:00-15:00 & -96.50 & -96.69 & -.98 .22 & -97.54 & - \\
15:00-18:00 & -95.54 & -97.07 & -98.27 & - & - \\
18:00-21:00 & -96.31 & -97.44 & -97.92 & -97.02 & - \\
21:00-00:00 & -94.88 & -96.96 & -97.76 & - & - \\
00:00-03:00 & -94.45 & -96.92 & -97.57 & - & - \\
03:00-06:00 & -96.08 & -97.06 & -97.40 & - & - \\
06:00-09:00 & -95.41 & -96.32 & -96.13 & - & - \\
\hline
\end{tabular}

Based on the table above, distribution of scattering volume value will change over time and depth, value of scattering volume increases at 21:00-00:00 because it is affected by the nature of zooplankton which will increase and decrease along with waters column. Prior to morning to midday, there seems down movement to deeper water. Zooplankton movement to water surface is began since 18:00 by SV value of $-97.02 \mathrm{~dB}$ and it reaches the peak at 00:00 by SV value of $-94.45 \mathrm{~dB}$. This aggregation will decrease at 03:00 by $\mathrm{SV}$ value of $-96.13 \mathrm{~dB}$. 


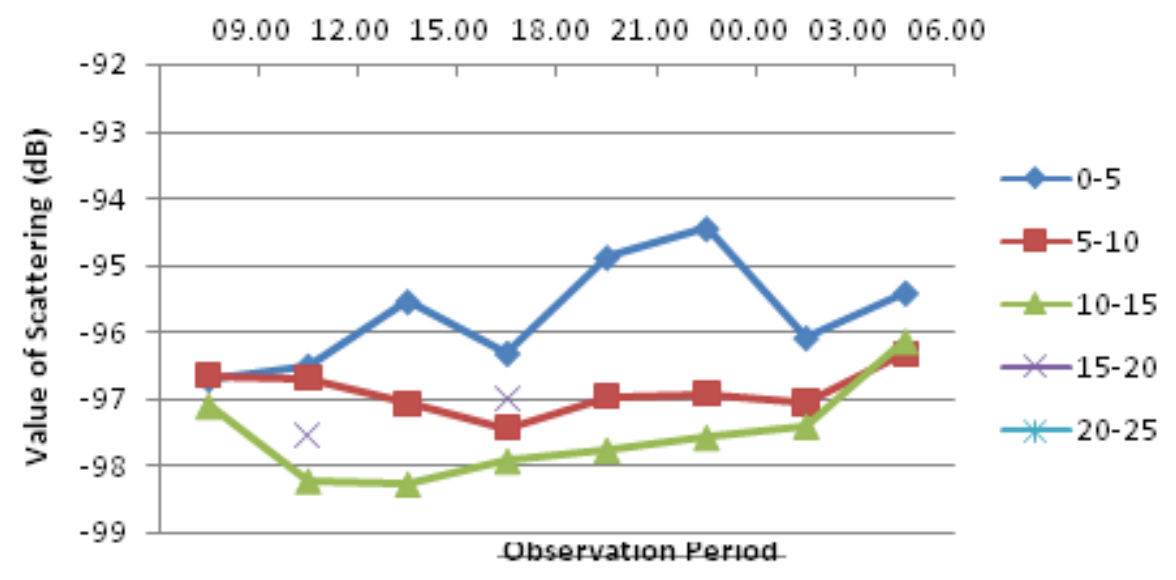

Figure 2. Value of time- and depth-based scattering volume

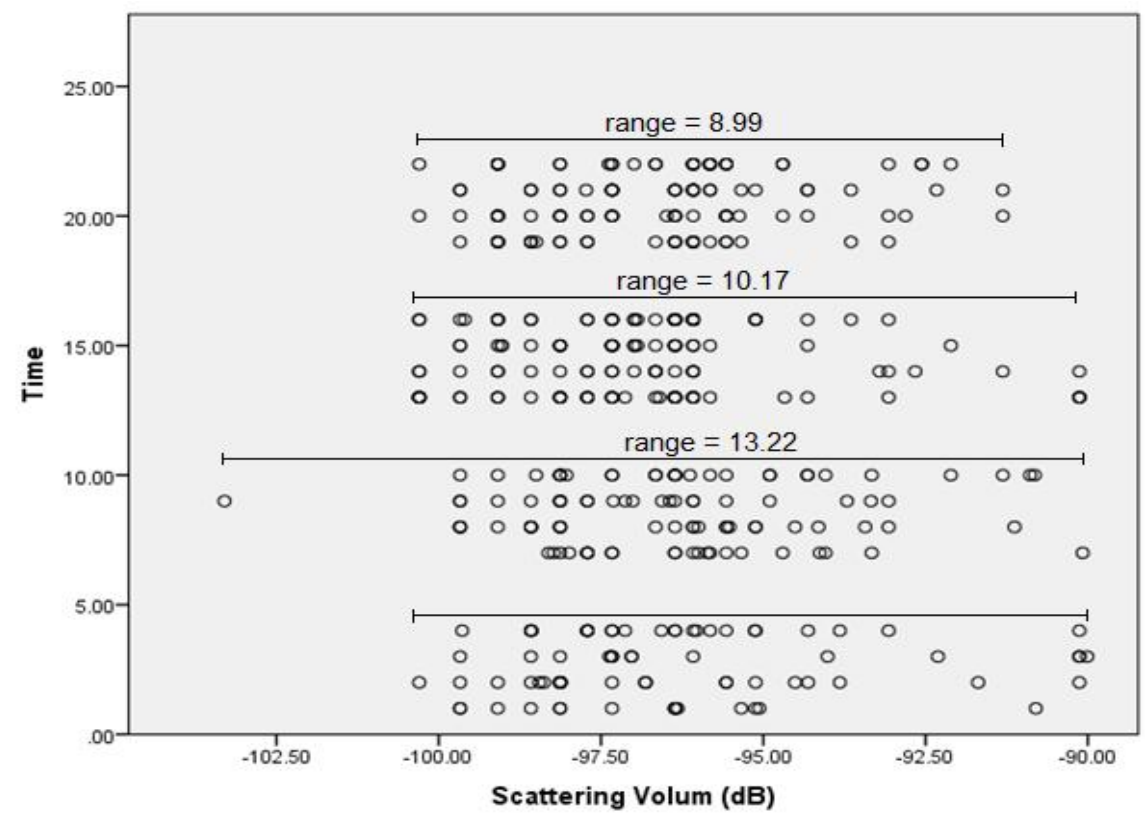

Figure 3. Value of Time-based Scattering Volume

Zooplankton will form dense layer at night and will scatter at noon. At 12:00-15:00, zooplankton will go down to depth of 15-20 m and will form multiple aggregations (Figure 2).

Table 2. Descriptive Statistics of Time-based Aggregation of Zooplankton

\begin{tabular}{|c|c|c|c|c|c|c|c|}
\hline \multicolumn{7}{|c|}{ Descriptive Statistics } \\
\hline Time & N & Range & Minimum & Maximum & Mean & Std. Deviation & Variance \\
\hline 00:00-06:00 & 75 & 10.29 & -100.30 & -90.01 & -96.3549 & 2.54946 & 6,500 \\
\hline 06:00-12:00 & 99 & 13.22 & -103.30 & -90.08 & -96.3645 & 2.28029 & 5,200 \\
\hline 12:00-18:00 & 128 & 10.17 & -100.30 & -90.13 & -96.9163 & 2.20222 & 4,850 \\
\hline 18:00-00:00 & 114 & 8.99 & -100.30 & -91.31 & -96.6166 & 1.98652 & 3,946 \\
\hline
\end{tabular}

Daily migration of zooplankton will form dense aggregation at night and will aggregate 
multiple numbers at noon. It is indicated by amount of $\mathrm{N}$ (aggregation amount) at 00:00 generating 75 groups and 128 groups at noon. At night, aggregation is formed in group with various group sizes (Table 2).

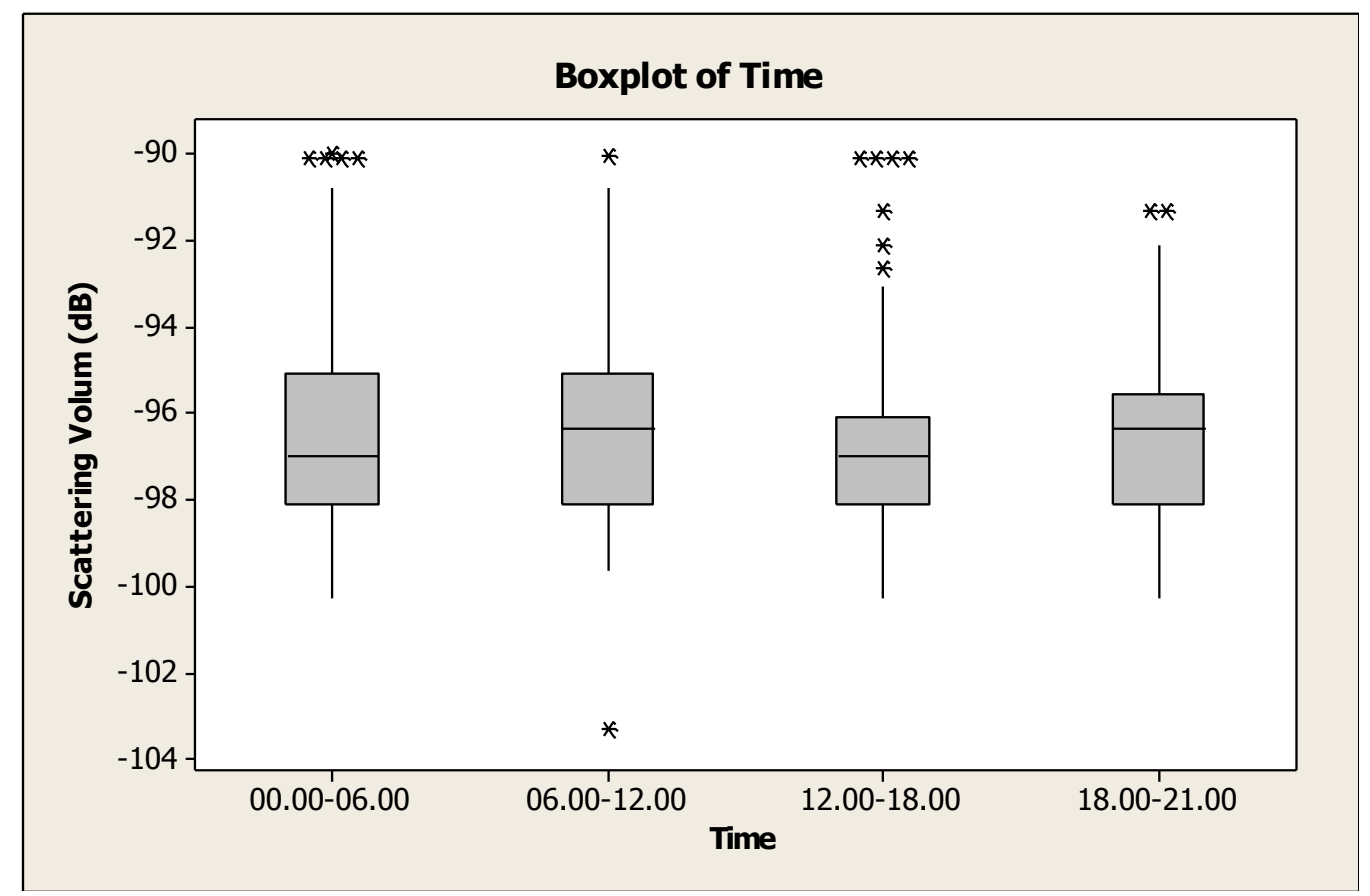

Figure 4. Scattering Volume Boxplot vs. Time.

The lowest average value occurs at 00:00-06:00, while the highest one occurs at observation time of 12:00-18:00. It indicates that at night, there exists quite dense aggregation where the size difference of inter-aggregation group may reach $2.5 \mathrm{~dB}$.

According to Sutomo et al. (1994), sometimes, there exists up to three layers migrating vertically where the movement will affect value of scattering volume. This value of scattering volume indicates the density of zooplankton. Aggregation contributes value of scattering volume. The study proves that layer of dense-state backscatter is formed in upper water column at night and it will disappear at noon.

According to Falk Petersen et al. (2007), spectrum size and energy content of dominant zooplankton species in arctic ecosystem determine the value which has been known that they become food sources for higher trophic level. It means that zooplankton aggregation will form spectrum having great energy content from the dominant zooplankton.

\subsection{Relationship between Biological Taxonomy of Zooplankton and Oceanographic Factor}

Biological data processing of zooplankton generates tabulation of individual amount as presented in Figure 5, zooplankton aggregation at 15:00 begins to move to water surface with density value of $20,500 \mathrm{ind} / \mathrm{m}^{3}$; this condition still remains until 03:00. Species contributing dominant value is Acrocalanus by density value of $8000 \mathrm{ind} / \mathrm{m}^{3}$, while species contributing in small number is Echinodermata larvae by density value of $450 \mathrm{ind} / \mathrm{m} 3$. 


\section{Macrothink Institute ${ }^{\text {tM }}$}

The findings show that domination of zooplankton group found in the study is mostly dominated by zooplankton species of Acrocalanus, Eucalanus, and Cyclopid. There has also found a group of Meroplankton when become temporary plankton (larvae) in its life cycle.

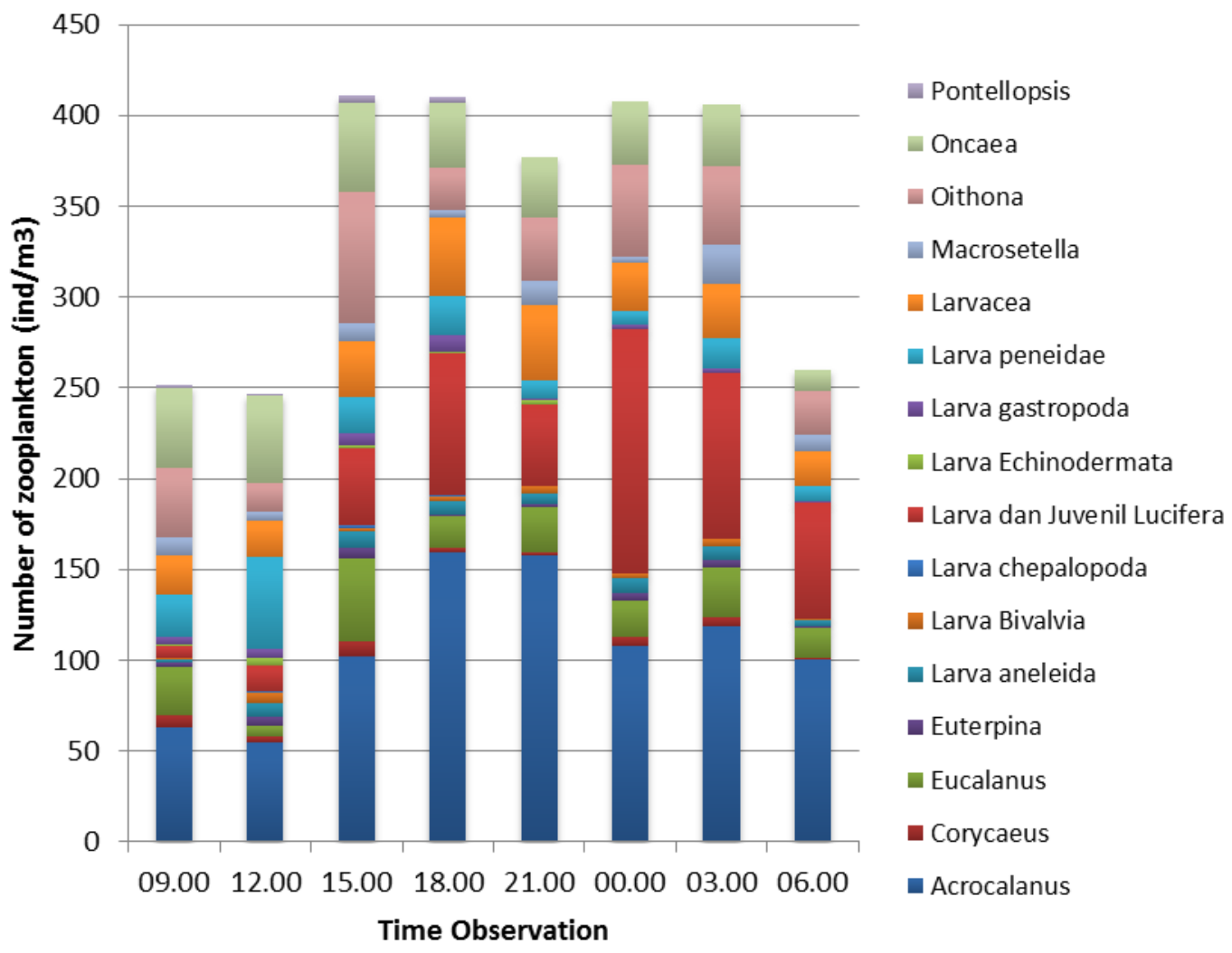

Figure 5. Composition of Observation time-based Zooplankton

Allegedly, acrocalanus is the greatest species which numerically becomes major contributor for the obtained value of scattering volume. This species is included in Calanoida since some parts of its body consist of joint hard epidermis and body segments.

Temperature is physical parameter having a role in managing ecological condition. Temperature changes often affect physical, chemical, and biological process in the ocean. Temperature in Inner Ambon Bay ranges from $26.4^{\circ} \mathrm{C}$ to $27.35^{\circ} \mathrm{C}$. Temperature rise greatly affects oxygen content which will directly relate to the growth of zooplankton; plankton will grow optimally at temperature range of $25^{\circ} \mathrm{C}-30^{\circ} \mathrm{C}$.

Zooplankton is herbivore of phytoplankton; it will respond fast when abundance change of phytoplankton occurs. In the food chain, zooplankton will be consumed by fish as its predator (Richarson, 2001).

According to Nicholas and Young (2006), many zooplankton species conducts diurnal migration vertically based on dietary pattern. At night, zooplankton will swim to sea surface and migrate to water column at noon. Many researchers attempt to explain this phenomenon, but they come to a conclusion that zooplankton movement is undertaken to avoid predators, as 
an effect of food availability, and as an environmental response (light and oxygen).

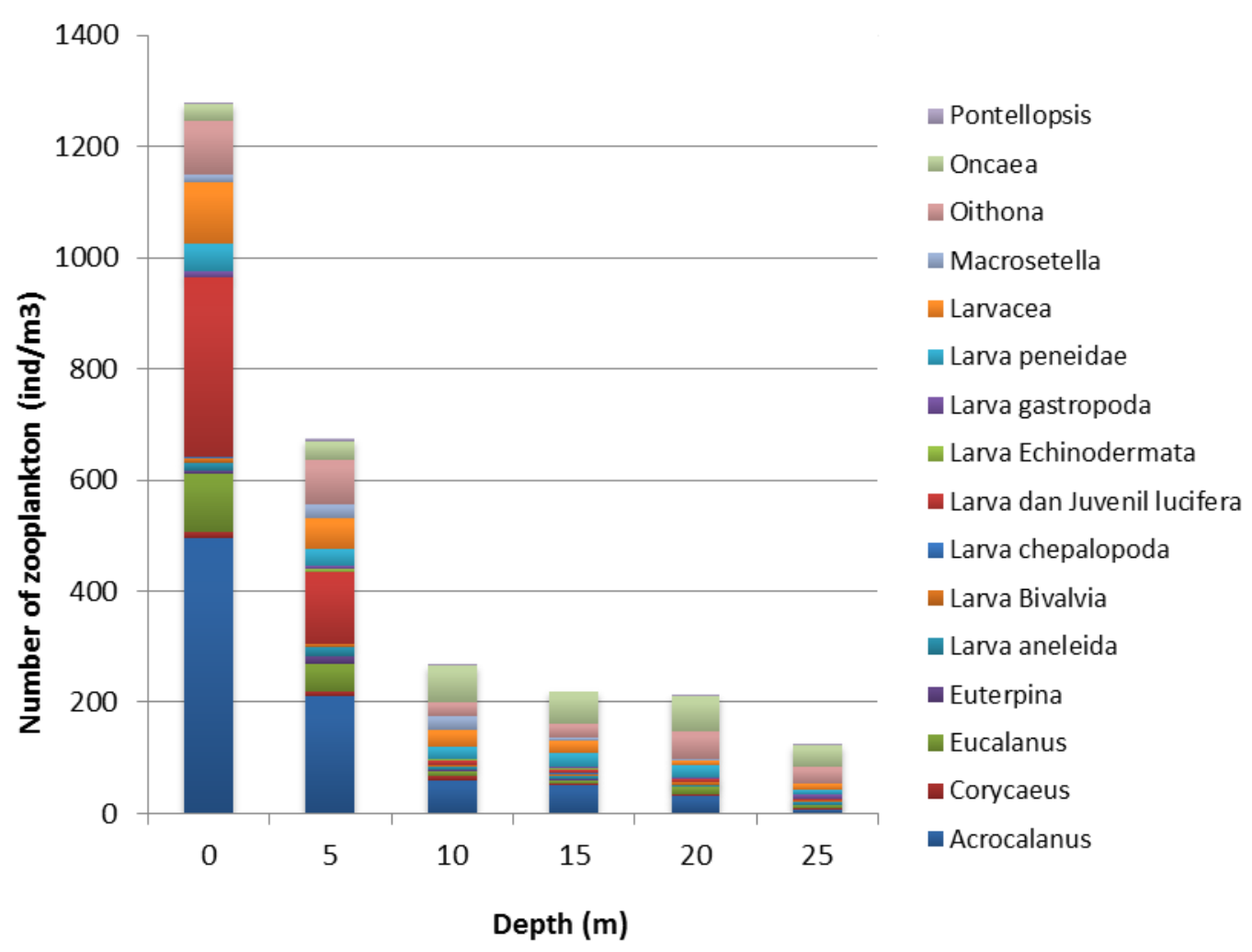

Figure 6. Composition of Depth-based Zooplankton

Figure 6 shows that zooplankton in Ambon Bay tends to swim in depth of 0 to 5 meter, and amount of this zooplankton will decrease along with the depth increase. Main cause of this phenomenon is that there are a lot of chlorophyll a in this depth as well as other oceanography factors.

Oceanographic transverse distribution in Inner Ambon Bay can be seen in Figure 7. Inner Ambon Bay is semi-closed waters when in certain time, dynamics of oceanography is relatively stable. In season in which winds come from the East, influence of Banda Sea will greatly affect the dynamics in this waters.

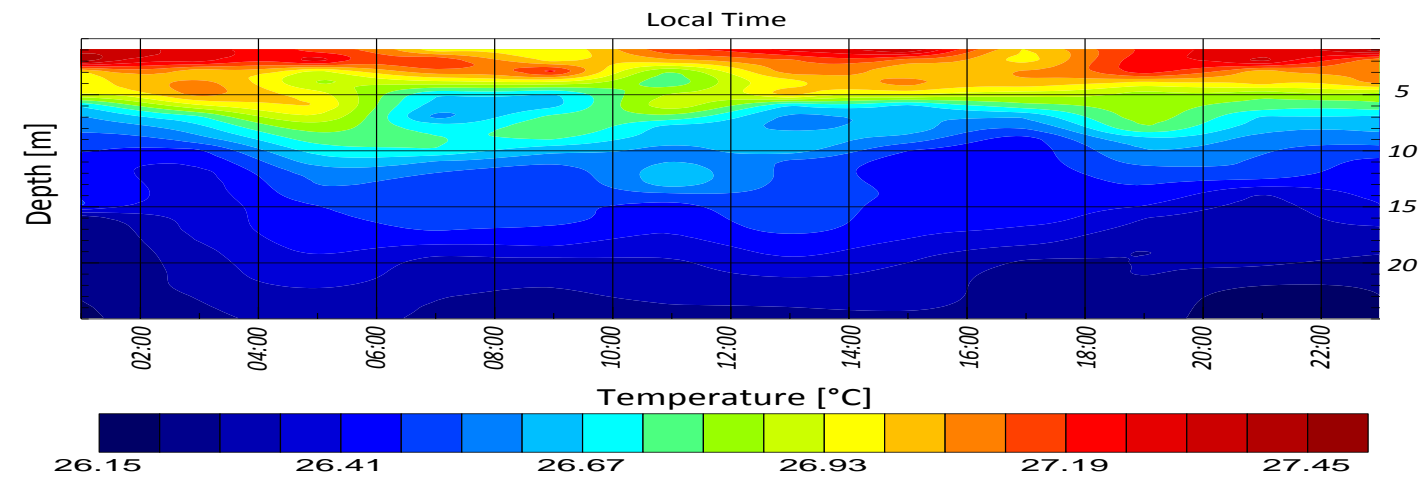



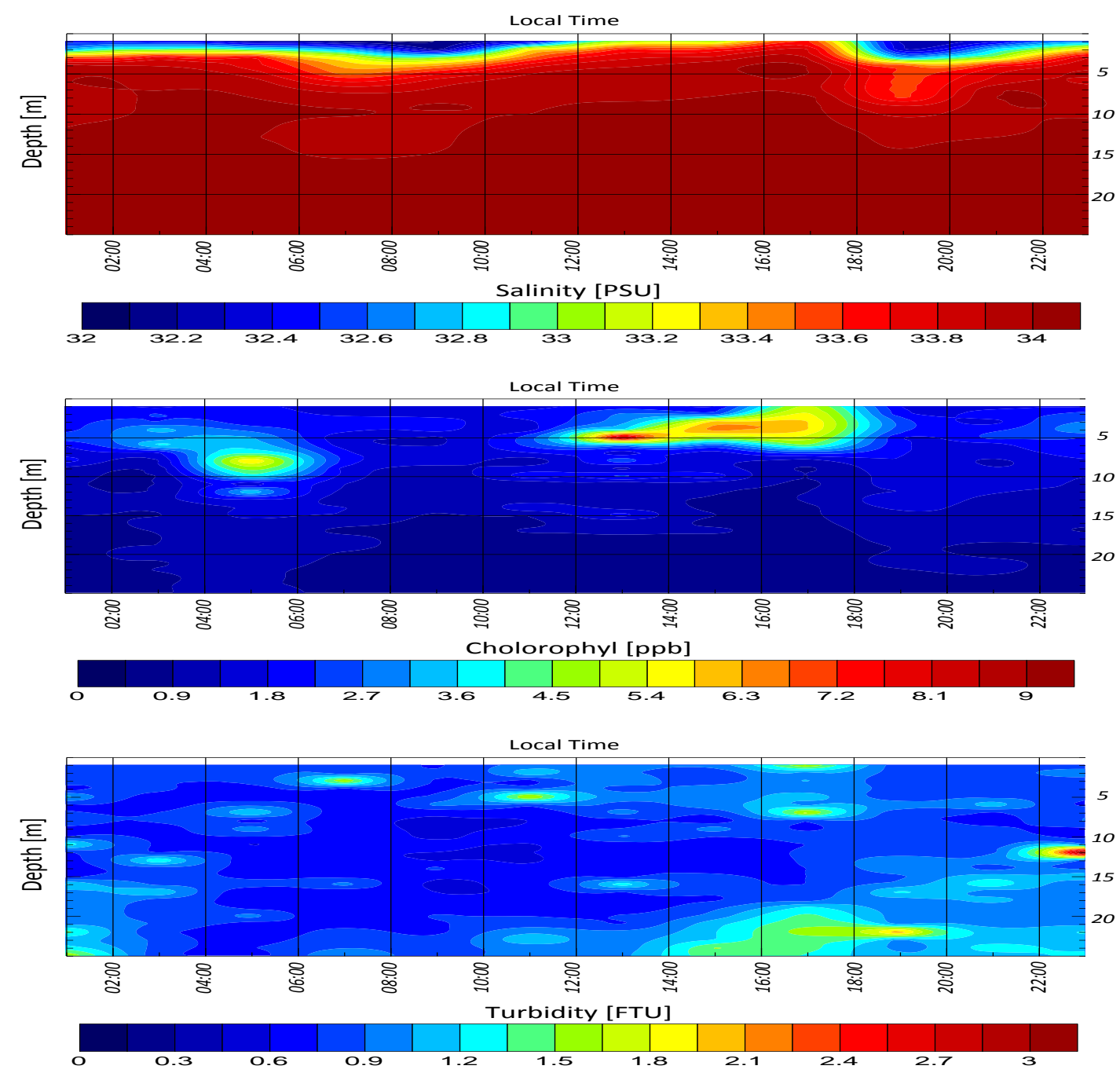

Figure 7. Oceanographic Transverse Distribution in Inner Ambon Bay

When the study is undertaken, maximum turbidity value is 2.1 FTU (Frequency Turbidity Unit and the lowest value is 0.7 (FTU). This turbidity value is triggered by high concentration of chlorophyll a 5.16 (ppb). Boyd (1979) states that turbidity may be triggered by particle suspension, which directly or indirectly will affect waters organisms. It can be seen in movement pattern of zooplankton at 15:00 to 03:00 indicating quite dense amount. This amount is dominant at depth of 0-5 meter (Figure 4). Zooplankton is predator of phytoplankton, while abundance of phytoplankton will firmly relate to chlorophyll a. One of stimuli in aggregation behavior is availability of food.

Salinity distribution in September is 34.04 PSU (Practicall Salinity Unit) where the increase of salinity will increase waters density. Salinity variation will temporarily or spatially change over times along with the influence of local variation from transportation rate through hydrological cycle. Inner Ambon Bay waters is estuary of some rivers running off to this bay, so salinity fluctuation will be firmly affected on how hydrological process occurs. According to Nontji (1987), salinity distribution in the sea is affected by multiple factors like water circulation pattern, evaporation, rainfall, and river current or surface runoff surrounding the 
waters.

\section{Conclusion}

Diurnal migration of zooplankton at noon is almost dispersed evenly to the entire waters by value of scattering volume $-100.30 \mathrm{~dB}$ to $-90.13 \mathrm{~dB}$ indicating sparse aggregation. While, at night, value of scattering volume ranges from $-100.30 \mathrm{~dB}$ to $-90.01 \mathrm{~dB}$ indicating dense aggregation.

Chlorophyll a concentration in depth of $0-10$ meter having value of $5.16 \mathrm{ppb}$ highly affects the existence of zooplankton. It is in consequence of aggregation and behavior of zooplanton which highly relate to food availability.

Ambon Bay waters is still proper for fishing ground of baitfish since this zooplankton-rich ocean has abundance value of $138,250 \mathrm{ind} / \mathrm{m}^{3}$. The amount is quite rich as food sources for pelagic fishes as the following trophic level in a food chain.

\section{Credits}

My best gratitude to Head of Ocean Acoustics Laboratory, Bogor Institute of Agriculture, Head of Ocean Conservation Research Station, The Indonesian Institute of Sciences (LembagaIlmuPengetahuan Indonesia or LIPI), Ambon for providing us equipments and facility for the study. Colleagues in the field, Mr. AsepMamun, S. Pi, Ir. J. Lekalette, Aunt Omi, La Imu, Malik Fajar. Crew of CNBK Pontoon Boat, Mr. Emo, Uncle Poly, Bryan, Remsy for all of their helps and jokes during the research.

\section{References}

Beamish P. (1971). Quantitative Measurment of Acoustic Scattering from Zooplankton Organism. Depp Sea Research. 18, 811-822.

Boyd, C. E. (1979). Water Quality in warm Fish Ponds.Oxford University Press. Oxford. 216.

Everson I. (1982). Diurnal variation in mean volume backscattering strengtg of an And Density off an antartic krill (Euphasia superba) patch, J. Plankton journal Res, 4(1), 155-162. http://dx.doi.org/10.1093/plankt/4.1.155

Falk. P., V. Porlov., Timofeev. Sand Sargent. J. R. (2007). Climate variability and possible effects on arctic, food chains. The role of the Calanus.Springer.Verlag. Berlin. Heidelberg. 147-166.

Hays, G. S., A. Richarson \& C. Robinson (2005). Climate change and marine Plankton. Trends Ecol. 20, 337-344. http://dx.doi.org/10.1016/j.tree.2005.03.004

Holiday, D. V dan R. E Pieper (1980). Volume scattering strength on zooplankton distributionat acoustic frequencies between 0.5 and $3 \mathrm{MHz}$. J. of the Acous Soc Am. 67(1), 135-146. http://dx.doi.org/10.1121/1.384472

Nicholas, R, \& B. Young, (2006). Pattern of diel vertical migration of zooplankton inAcoustic Doppler velocity and backscatter data on the Newfoundland. Canadian Journal of fisheries 


\section{Macrothink}

and Aquatic Sciences, 63(12), 2708-2721. http://dx.doi.org/10.1139/f06-157

Nontji, A. (1987). Laut Nusantara. Penerbit Djambatan . Jakarta

Richardson A. (2001). Oceans. Compass Point Book

Selanno DAJ. (2011). Beban Pencemaran Pada Ekosistim Teluk: Perspektif Pengelolaan Kualitas Lingkungan Laut. IPB Press. 160 hal.

Stanton,T K, D. Chu, P. Wiebe, L. V. Martin dan R. Eastwood, (1998). Sound scattering By several zooplankton group.I.Eksperimental determination of dominant Scattering mechanism. J. of Acoust. Soc. of Am. 103(1), 225-235. http://dx.doi.org/10.1121/1.421469

Sutomo, A. B. dan Nugroho, D. (1994). Penggunaan Fish Finder dan Jaring Nansen untukstudimigrasivertikal zooplankton. Makalahdibacakanpada symposium Perikanan Indonesia. Jakarta 25-27 Agustus 1993.

Wagey, G. A. (2002). Ecology and Physiology of Phytoplankton in Ambon Bay. Indonesia. Thesis Submitted in Partial Fulfillment of the Requirements for the Degree of Doctor of Philosophy in The Faculty of Graduate Studies (Department of earth And Ocean Sciences, Oceanography) The University of British Columbia. 185p

Wickstead, J. H. (1965). An introduction to the study of tropical plankton, vol 1, 1-60 London. Hutchinson Tropical Monograph.

\section{Copyright Disclaimer}

Copyright for this article is retained by the author(s), with first publication rights granted to the journal.

This is an open-access article distributed under the terms and conditions of the Creative Commons Attribution license (http://creativecommons.org/licenses/by/3.0/). 